\title{
Effect of Stem Cell Therapy on Gentamicin Induced Testicular Dysfunction in Rats
}

Mohamed SM1, ElHawary NM¹, Mohamed SF${ }^{1}$, Hashim NI ${ }^{1}$, Saleh SY², Bakeer MR ${ }^{2}$ and Sawiress FA ${ }^{2 *}$

${ }^{1}$ Department of Physiology, Faculty of Medicine, Al-Azhar University, Egypt

${ }^{2}$ Department of Physiology, Faculty of Veterinary Medicine, Cairo University, Giza, Egypt

\begin{abstract}
Infertility is a worldwide problem affecting couples that have unprotected intercourse, so the current study investigated the possible ameliorative effect of intra testicular stem cell injection in rats subjected to gentamicin induced testicular degeneration. For this study 100 male rats were randomly allocated into 4 groups, namely, the control group (group I), gentamicin group (group II), stem cell group (group III) and gentamicin and stem cell group (group IV). Gentamicin was administered daily for 2 weeks ( $80 \mathrm{mg} / \mathrm{kg}$ ) to groups (II and IV). Stem cells were injected intra testicular into rete testis once by the end of gentamicin administration in group (IV) or after I/P injection of saline in group III. Blood and testicular samples were collected by the end of weeks 2, 6 and 10 from group (I) and (II), and by the end of weeks 6 and 10 from group (III and IV). The obtained results showed a significant decreases in serum testosterone, testicular testosterone and estradiol, sperm counts, sperm viability and an increase in $\%$ of fragmented DNA (indicating degenerative and necrotic changes) in testicular tissue of group (II) compared to group I, III and IV. Mesenchymal stem cells administration significantly improved all altered testicular parameters, where values of group IV (except testicular estradiol) were not significantly different from those of control group (I). Conclusively, mesenchymal stem cells proved to be beneficial in rats subjected to gentamicin induced testicular dysfunctions.
\end{abstract}

Keywords: Gentamicin; Stem cells; Testicular dysfunction

\section{Introduction}

Populations are increasingly suffering from infertility [1]. Male infertility is of concern and it accounts for about $20-30 \%$ of infertility cases and contribute to $50 \%$ of infertility cases overall [2]. Causes of fertility are diverse; including varicocele, infections, ejaculation issues, anti-sperm antibodies, tumours affecting the male reproductive organs or the glands that release hormones related to reproduction such as the pituitary gland, surgery, radiation or chemotherapy to treat tumours, hormone imbalances, sperm duct defects, chromosome defects as Klinefelter's syndrome, cystic fibrosis, Kallmann's syndrome, Young's syndrome and Kartagener syndrome, certain disease as Celiac disease, and environmental causes [3,4]. In the last few years, a marked decrease in the quality of semen has been reported [5]. These changes in semen quality are more likely to be due to environmental factors, including chemicals and drugs which are particularly misused [6]. Antibiotics are commonly prescribed for a multitude of everyday condition. Not surprisingly, a proportion of male patients attending fertility clinics may have been prescribed antibiotics by their general practitioner to treat these unrelated infections [7]. Among these antibiotics comes gentamicin. Gentamicin is the aminoglycoside of first choice because of its low cost and reliable activity against the most resistant gram-negative aerobes [8]. The most frequently reported adverse effects associated with gentamicin therapy are testicular dysfunction, nephrotoxicity and ototoxicity $[9,10]$. Moreover, gentamicin used in neonatal sepsis and other systemic infections, inhibits cell division of germ cells and protein synthesis in the testis, induces cell death in the seminal vesicle, thus gentamicin was known to reduce sperm count, sperm motility, and sperm viability.

Stem cells, defined as cells with extensive renewal capacity and the ability to generate daughter cells that undergo further differentiation [11]. The self-renewal and differentiation activity of stem cells are controlled by their surrounding niches. Stem cell niches are defined as the cellular and molecular microenvironments that regulate stem cell function which includes control of the balance between quiescence, self- renewal, and differentiation of stem cells [12]. The primary role of adult stem cells in a living organism is to maintain and repair the tissue in which they are found. Adult stem cells have been identified in many organs and tissues, including bone marrow.

It was documented that culture-expanded Mesenchymal Stem Cells (MSCS) did not have MHC class II cell surface markers, but rather only MHC class I, thus MSCs could be used therapeutically as allogeneic cells, so called universal cells [13], and not antigen-presenting cells that would be invisible to the host's immune system [14]. Also mesenchymal stem cells are particularly suitable for cell therapy because of easy isolation, high expansion potential giving unlimited pool of transplantable cells, low immunogenicity, amenability to in vivo genetic modification, and multipotency [15]. It was found that, injection of stem cells into the brains of dogs have shown to be very successful in treating cancerous tumours by using conventional techniques [16]. Similarly, several clinical trials targeting heart disease have shown that adult stem cell therapy is safe, effective, and equally efficient in treating old and recent infarcts [17]. Thus, the aim of the present investigation is to test the potential regenerative effects of stem cells to maintain, improve and rescue testicular functions in rats subjected to gentamicin induced testicular degeneration.

\section{Materials and Methods}

Animals: Hundred and ten adult male Sprague-Dawely rats,

*Corresponding author: Francois Amin Riad Sawiress, Department of Physiology, Faculty of Veterinary Medicine, Cairo University, Giza 12211, Egypt, Tel: 202-24871116; E-mail: francoisawiress@hotmail.com

Received May 13, 2017; Accepted June 13, 2017; Published June 15, 2017

Citation: Mohamed SM, ElHawary NM, Mohamed SF, Hashim NI, Saleh SY, et al (2017) Effect of Stem Cell Therapy on Gentamicin Induced Testicular Dysfunction in Rats. J Health Med Informat 8: 263. doi: 10.4172/2157-7420.1000263

Copyright: ( 2017 Mohamed SM, et al. This is an open-access article distributed under the terms of the Creative Commons Attribution License, which permits unrestricted use, distribution, and reproduction in any medium, provided the original author and source are credited. 
weighing 150-200 g. Rats were housed in plastic cages (5 rats/cage) in the animal house of Department of Veterinary Medicine, Cairo University, and were acclimatized for 2 weeks before use in the study. They were kept under hygienic condition at room temperature with free access to water and ordinary rat chow.

\section{Experimental design}

After the period of accommodation, ten rats were used as donors for mesenchymal bone marrow stem cells, and another 100 rats were assigned to 3 groups to evaluate the therapeutic effect of mesenchymal stem cells on gentamicin induced testicular dysfunction.

Group I (control, N=30): Rats were left without any treatment, but intrapretoneal injected with $0.4 \mathrm{ml}$ saline $(0.85 \%)$. Samples were collected at the end of the $2^{\text {nd }}, 6^{\text {th }}$ and $10^{\text {th }}$ weeks ( 10 rats/week).

Group II (gentamicin, N=30): Rats were injected I.P. daily with gentamicin $(80 \mathrm{mg} / \mathrm{kg}$ body weight) for 2 weeks to induce testicular dysfunction. The dose and duration were selected according to pilot study. Samples were collected at the end of the $2^{\text {nd }}, 6^{\text {th }}$ and $10^{\text {th }}$ weeks ( 10 rats/week) so as to cover the duration of spermatogenesis.

Group III (stem cells group, N=20): Rats were injected I.P. daily with saline for 2 weeks, followed by injection intratesticular into rete testis once with $10 \mu \mathrm{l}$ of cell suspension of mesenchymal bone marrow stem cells/rat. Samples were collected at the end of the $6^{\text {th }}$ and $10^{\text {th }}$ weeks (10 rats/week).

Group IV (gentamicin+stem cells, $\mathrm{N}=20$ ): Gentamicin (80 mg/ $\mathrm{kg}$ body weight) was injected I.P daily for 2 weeks to induce testicular dysfunction. At the end of the $2^{\text {nd }}$ week, rats were injected intra testicular into rete testis once with $10 \mu \mathrm{l}$ of cell suspension of mesenchymal bone marrow stem cells/rat. Samples were collected at the end of the $6^{\text {th }}$ and $10^{\text {th }}$ weeks (10 rats/week)

Mesenchymal stem cells administration: Stem cell administration was accomplished according to the method of Yan et al. [18].

Blood sampling: Under light ether anaesthesia, blood was collected from rats using the orbital sinus technique; sera were separated and stored at $-20^{\circ} \mathrm{C}$ for estimation of serum testosterone.

Testicular tissue sampling: Under ether anaesthesia, the testes of all rats were excised according to their specified times. In each rat, one testis was washed with $0.9 \% \mathrm{NaCl}$ and stored at $-80^{\circ} \mathrm{C}$ to be homogenized while the other testis was used for histopathological examination (Bancroft and Gamble 2002).

\section{Homogenization of testicular tissue}

1. About $30 \mathrm{mg}$ of testicular tissue were homogenized in 175 lyses buffer for $10 \mathrm{~min}$. and then tissue centrifuged for $20 \mathrm{~min}$ at $15000 \times \mathrm{g}$

2. Three hundred and fifty $\mu \mathrm{l}$ of SV RNA Diluting Buffer was added to $175 \mu \mathrm{l}$ of tissue homogenate; it was mixed by inverting the tube 3-4 times. The mixture was placed in a water bath at $70^{\circ} \mathrm{C}$ for $3 \mathrm{~min}$

3. The mixture was centrifuged at $12,000-14,000 \times \mathrm{g}$ for $10 \mathrm{~min}$ at $20-25^{\circ} \mathrm{C}$.

4. The supernatant was taken for estimation of testicular tissue testosterone, estradiol hormone and \% of fragmented DNA.

\section{Collection of epididymal sperms}

Epididymal sperms were collected by cutting the caudal region of the epididymis into small pieces and flushing the sperms in $15 \mathrm{ml}$ Ringer's solution at $32^{\circ} \mathrm{C}$. The collected sperms were used for estimation of sperm count and viability.

Estimation of sperm concentration (count): Epididymal samples were counted according to Bancroft and Gamble [19].

Estimation of sperm viability by sperm viability test: It was accomplished by Eosin Nigrosin method according to Adamkovicova et al. [20].

Isolation of bone marrow derived mesenchymal stem cells from rats: Mesenchymal stem cells were easily obtained using a simple bone marrow aspiration from the tibia and femur bones of rats according to the method of Alhadlaq and Mao; Patel et al. [21,22], after which it was subsequently cultured with its nutritional solution and antibiotics to be incubated and expanded in vitro until developing into large colonies [23].

Identification of bone marrow derived mesenchymal stem cells from rats: Mesenchymal stem cells in culture were characterized by their adhesiveness and fusiform shape and by detection of CD29, one of the surface markers of rat mesenchymal stem cells [24].

RT-PCR detection of CD29 gene expression: For detection of CD29 gene expression, RNA was extracted, reversely transcribed and amplified by PCR and visualized using agarose gel electrophoresis [25].

Estimation of serum and testicular testosterone hormone: Serum total testosterone and testicular testosterone were determined using ELISA kits of DRG International, Inc. USA according to Wayne [26].

Estimation of testicular estradiol hormone: Testicular tissue estradiol was determined by Estradiol ELISA Kit, Bio-Line USA according to Gore [27].

Determination \% of fragmented DNA: DNA fragmentation was measured according to Boraschi and Maurizi [28].

Histopathological examination of testicular tissue: Histopathological examination was done by the light microscope according to the method of Drury and Wallington [29].

Descriptive statistics: Quantitative data were expressed as mean and Standard Error (S.E.) of mean.

Analytical statistics: Comparing groups were done using: Student T test, and Analysis of variance (ANOVA) for comparison of quantitative data of more than 2 groups. The level of significance was taken at $\mathrm{P}$ value of $<0.05$ according to Snedecor and Cochran [30].

\section{Results}

\section{The results of the present study were organized in the following data}

Effect of gentamicin injection on all tested parameters at the end of $2^{\text {nd }}$ week, $6^{\text {th }}$ week and $10^{\text {th }}$ week: Tables $1-3$ illustrate the changes at the $2^{\text {nd }}$ week in all tested parameters in control group (group I) and after 2 weeks of gentamicin injection (group II).

Serum testosterone and testicular testosterone: Tables 1-3, 2 weeks of gentamicin injection induced a significant decrease in serum and testicular testosterone in comparison to control $(\mathrm{p}<0.05)$.

Estradiol in testicular tissue: Tables 1-3 showed that 2 weeks of gentamicin injection induced a significant decrease in testicular estradiol in comparison to control $(\mathrm{p}<0.05)$. 


\begin{tabular}{|c|c|c|}
\hline \multirow{2}{*}{ Parameters } & \multicolumn{2}{|c|}{ Experimental groups } \\
\cline { 2 - 3 } & Group I & Group II \\
\hline Serum testosterone $(\mathrm{ng} / \mathrm{ml})$ & $3.9 \pm 0.10$ & $0.51^{\mathrm{a}} \pm 0.05$ \\
\hline Testicular testosterone $(\mathrm{ng} / \mathrm{mg})$ & $4.77 \pm 0.12$ & $0.73^{\mathrm{a}} \pm 0.06$ \\
\hline Testicular estradiol $(\mathrm{pg} / \mathrm{mg})$ & $58.86 \pm 0.34$ & $40^{\mathrm{a}} \pm 0.93$ \\
\hline Percentage of fragmented DNA & $13.94 \pm 0.68$ & $42.43^{\mathrm{b}} \pm 1.67$ \\
\hline Sperm count $\left(\mathrm{million} / \mathrm{mm}^{3}\right)$ & $98 \pm 0.41$ & $30^{\mathrm{a}} \pm 1.05$ \\
\hline Sperm viability $\%$ & $97.57 \pm 0.51$ & $67.29^{\mathrm{a}} \pm 1.63$ \\
\hline
\end{tabular}

Data indicate Mean \pm S.E. Number of rats in each group $=10$; a: Significant decrease at $(P<0.05)$ versus control group (group I); b: Significant increase at $(P<0.05)$ versus control group (group I); **: \% of fragmented DNA in testicular tissue

Table 1: Comparison between all tested parameters of group I (control) and group II (gentamicin) at the end of $2^{\text {nd }}$ week after gentamicin injection. Group I: Control; Group II: 2 weeks of Gentamicin, sampling after 6 weeks.

\begin{tabular}{|c|c|c|c|c|}
\hline \multirow{2}{*}{ Parameters } & \multicolumn{4}{|c|}{ Experimental groups } \\
\cline { 2 - 5 } & Group I & Group II & Group III & Group IV \\
\hline $\begin{array}{c}\text { Serum testosterone } \\
(\mathrm{ng} / \mathrm{ml})\end{array}$ & $3.63 \pm 0.15$ & $1.13^{\mathrm{a}} \pm 0.03$ & $3.96 \pm 0.18$ & $3.19^{\mathrm{c}} \pm 0.22$ \\
\hline $\begin{array}{c}\text { Testicular } \\
\text { testosterone }(\mathrm{ng} / \mathrm{mg})\end{array}$ & $4.44 \pm 0.16$ & $1.27^{\mathrm{a}} \pm 0.02$ & $4.79 \pm 0.15$ & $4.21^{\mathrm{c}} \pm 0.15$ \\
\hline $\begin{array}{c}\text { Testicular Estradiol } \\
\text { (pg/mg) }\end{array}$ & $58.86 \pm 0.34$ & $38.00^{\mathrm{a}} \pm 0.14$ & $58.0 \pm 0.53$ & $55.57 \pm 1.29$ \\
\hline $\begin{array}{c}\% \text { of fragmented } \\
\text { DNA** }\end{array}$ & $12.14 \pm 0.43$ & $43.43^{\mathrm{b}} \pm 0.32$ & $12.57 \pm 0.53$ & $13.71 \pm 0.94$ \\
\hline $\begin{array}{c}\text { Sperm count } \\
\text { (million/mm3) }\end{array}$ & $96.00 \pm 1.47$ & $41.00^{\mathrm{a}} \pm 0.2$ & $98.14 \pm 0.74$ & $96.14 \pm 1.18$ \\
\hline Sperm viability \% & $94.29 \pm 0.96$ & $48.43^{\mathrm{a}} \pm 0.7$ & $97.29 \pm 0.61$ & $96.00 \pm 0.49$ \\
\hline
\end{tabular}

Data indicate Mean \pm S.E. Number of rats in each group $=10$; a: Significant decrease $(\mathrm{P}<0.05)$ versus control group I and group IV (GM for 2 weeks after $6^{\text {th }}+$ stem cells) b: Significant increase $(P<0.05)$ versus control group I and group IV; c: Significant decrease $(\mathrm{P}<0.05)$ versus group III; **: \% of fragmented DNA in testicular tissue

Table 2: Comparison of all tested parameters between group I (control), group I (gentamicin), group III (vehicle for 2 weeks+stem cell therapy) and group IV (Gen. for 2 weeks+stem cells therapy) at the end of 6 weeks.

\begin{tabular}{|c|c|c|c|c|}
\hline \multirow{2}{*}{ Parameters } & \multicolumn{4}{|c|}{ Experimental groups } \\
\cline { 2 - 5 } & Group I & Group II & Group III & Group IV \\
\hline $\begin{array}{c}\text { Serum testosterone } \\
\text { (ng/ml) }\end{array}$ & $3.89 \pm 0.1$ & $1.22^{\mathrm{a}} \pm 0.02$ & $4.28 \pm 0.24$ & $3.63 \pm 0.18$ \\
\hline $\begin{array}{c}\text { Testicular } \\
\text { testosterone }(\mathrm{ng} / \mathrm{mg})\end{array}$ & $4.73 \pm 0.13$ & $1.28^{\mathrm{a}} \pm 0.03$ & $4.80 \pm 0.17$ & $4.24 \pm 0.20$ \\
\hline $\begin{array}{c}\text { Testicular Estradiol } \\
(p g / m g)\end{array}$ & $58.86 \pm 0.34$ & $35.00^{\mathrm{a}} \pm 0.22$ & $59.29 \pm 0.61$ & $58.29 \pm 0.68$ \\
\hline $\begin{array}{c}\text { \% of fragmented } \\
\text { DNA }\end{array}$ & $13.00 \pm 0.68$ & $42.14^{\mathrm{b}} \pm 0.27$ & $13.29 \pm 0.68$ & $12.71 \pm 0.68$ \\
\hline $\begin{array}{c}\text { Sperm count(million/ } \\
\left.\mathrm{mm}^{3}\right)\end{array}$ & $97.57 \pm 0.36$ & $31.14^{\mathrm{a}} \pm 0.08$ & $97.86 \pm 0.34$ & $97.00 \pm 0.44$ \\
\hline Sperm viability \% & $92.86 \pm 0.56$ & $41.86^{\mathrm{a}} \pm 0.81$ & $94.00 \pm 1.31$ & $92.00 \pm 1.23$ \\
\hline
\end{tabular}

Data indicate Mean \pm S.E. Number of rats in each group=10; a: Significan decrease $(P<0.05)$ versus control group I and group IV (GM for 2 weeks after $10^{\text {th }}+$ stem cells); b: Significant increase $(P<0.05)$ versus control group I and group IV; c: Significant decrease $(P<0.05)$ versus group III; **: \% of fragmented DNA in testicular tissue

Table 3: Comparison of all tested parameters between group I (control), group II (gentamicin), group III (vehicle for 2 weeks+stem cell therapy) and group IV (Gen. for 2 weeks+stem cells therapy) at the end of 10 weeks.

Percentage of fragmented DNA in testicular tissue: Tables 1-3 revealed that 2 weeks of gentamicin injection induced a significant increase in \% of fragmented testicular DNA in comparison to control $(\mathrm{p}<0.05)$.

Sperm count and viability: Tables $1-3$ revealed that 2 weeks of gentamicin injection induced a significant decrease in sperm count and viability $\%$ in comparison to control $(\mathrm{p}<0.05)$.
II- Effect of stem cell therapy on 2 weeks of vehicle or gentamicin injection on all tested parameters at the end of $6^{\text {th }}$ week: Table 2 illustrated the changes at the end of $6^{\text {th }}$ week in all tested parameters of the gentamicin+stem cells group (group IV) compared to the gentamicin group (II), stem cell group (group III) and the control group (group I).

Serum and testicular testosterone: (Table 2) showed that serum and testicular testosterone levels were significantly increased in group (IV) compared to group (II). Values of group (IV) were not significantly different from those of the control, but were lower significantly than those of group (III).

Estradiol in testicular tissue: (Table 2) showed that testicular estradiol levels were significantly increased in group (IV) compared to group (II). Values of group (IV) decreased significantly compared to those of the control; meanwhile they did not differ significantly compared to group (III).

Percentage of fragmented DNA in testicular tissue: Table 2 revealed that there was a significant decrease in percentage of fragmented DNA in testicular tissue of group (IV) compared to group (II), meanwhile, the percentage of the same group did not differ significantly when compared to group (I, III) 4 .

Sperm count and viability : (Table 2) revealed that there was a significant increase in sperm count and viability of group (IV) compared to group (II), meanwhile, the values of the same group did not differ significantly when compared to group (I, III).

II-b Effect of stem cell therapy on 2 weeks of vehicle or gentamicin injection on all tested parameters at the end of $10^{\text {th }}$ week: Table 3 illustrated the changes at the end of $10^{\text {th }}$ week in all tested parameters of the gentamicin+stem cell group (group IV) compared to the gentamicin group (II), stem cells group (III) and the control group (group I).

Serum and testicular testosterone: (Table 3 ) showed that serum and testicular testosterone levels were significantly increased in group (IV) compared to group (II). Values of group (IV) were not significantly different from those of the control, and stem cells group.

Estradiol in testicular tissue: (Table 3) showed that testicular estradiol levels were significantly increased in group (IV) compared to group (II). Values of group (IV) were not significantly different compared to those of groups I and III.

Percentage of fragmented DNA in testicular tissue: Table 3 revealed that there was a significant decrease in percentage of fragmented DNA in testicular tissue of group (IV) compared to group (II), meanwhile, the percentage of the same group did not differ significantly when compared to groups I and III.

Sperm count and viability: Table 3 revealed that there was a significant increase in sperm count and viability of group (IV) compared to group (II), meanwhile, the values of the same group did not differ significantly when compared to group I and III.

\section{Histopathological changes}

Group I: (Testes of control group): Testes: There was no histopathological alteration and the normal histological structure of the mature active seminiferous tubules with complete spermatogenic series of primary, secondary and tertiary spermatogonia with Sertoli cells in between on the basement membrane were recorded in Figure 1. 
Citation: Mohamed SM, ElHawary NM, Mohamed SF, Hashim NI, Saleh SY, et al. (2017) Effect of Stem Cell Therapy on Gentamicin Induced Testicular Dysfunction in Rats. J Health Med Informat 8: 263. doi: 10.4172/2157-7420.1000263

Page 4 of 8

Group II: Two weeks of gentamicin injection.

At the $2^{\text {nd }}$ week: Testes: Degenerative change was detected in some individual seminiferous tubules which were characterized by loss of the spermatogenic series of the spermatocytes while the basement membrane showed only one cell layer of primary spermatocytes without Sertoli cells (Figure 2).

At the $6^{\text {th }}$ week: Testes: Most of the seminiferous tubules showed loss of cell detail and presence of the general architecture as a coagulative type of necrosis while the interstitial stroma was hyalinized and had remnant of pyknotic nuclei of the cells as well as some inflammatory cells complete absence of spermatogenesis was recorded in most of the tubules (Figure 3).

At the $10^{\text {th }}$ week: Testes: The seminiferous tubules showed complete loss of cellular spermatogenic series as well as the basement membrane and were replaced by homogenous eosinophilic to basophilic un detailed structure material while the general architecture was present (coagulative necrosis) associated with fibrosis in between the tubules (Figure 4).

\section{Group III: Stem cells group.}

There was no histopathological alteration and the normal mature active seminiferous tubules with complete spermatogenic series were recorded. The interstitial stromal cells as well as the blood vessels were

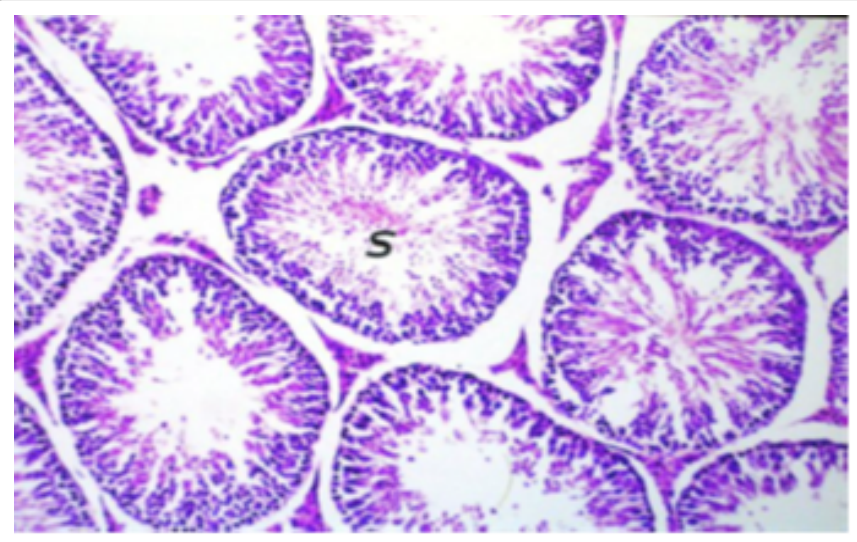

Figure 1: Histological picture of Control group. Testis showing intact normal histological structure of seminiferous tubules with complete spermatogenic series.

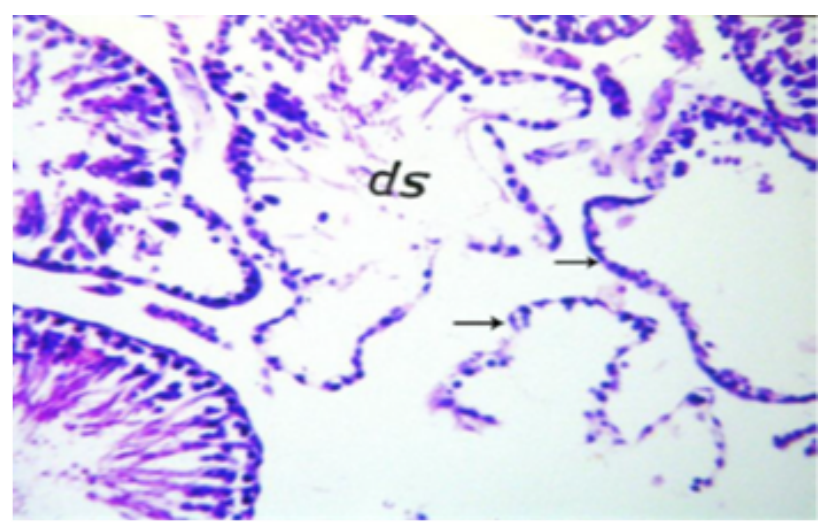

Figure 2: Two weeks of gentamicin injection, testis showing irregular outline (arrow) of the degenerated seminiferous tubules (ds). localized in triangular area between the tubules (Figure 5). Spermatozoa were impacted in the lumen of the seminiferous tubules.

Group IV: Stem cell therapy and 2 weeks of gentamicin injection.

At the $6^{\text {th }}$ week: Most of the seminiferous tubules showed complete spermatogenic series with appearance of spermatozoa in the tubular lumen (Figure 6).

At the $10^{\text {th }}$ week: The seminiferous tubules showed complete

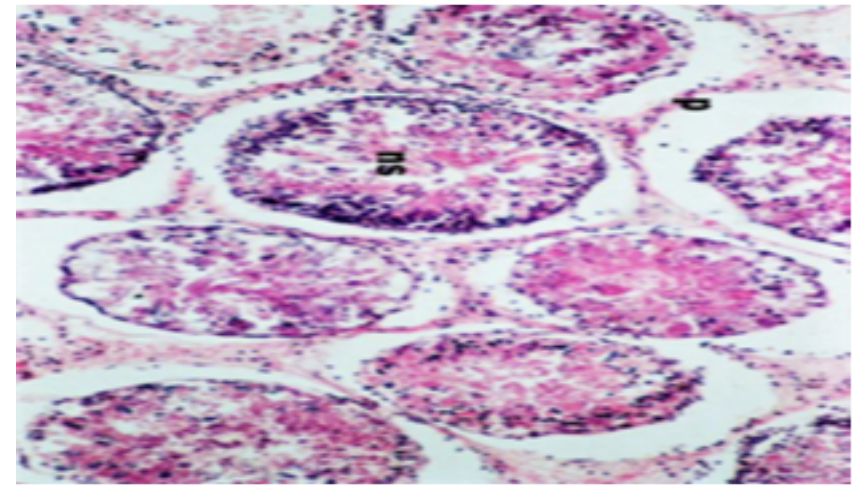

Figure 3: Two weeks of gentamicin injection after 6 weeks, testis of rat showing necrosis in seminiferous tubules (ns) with hyalinization of stromal connective tissue with presence of pyknotic nuclei $(p)$ and inflammation cells infiltration $(\mathrm{m})$

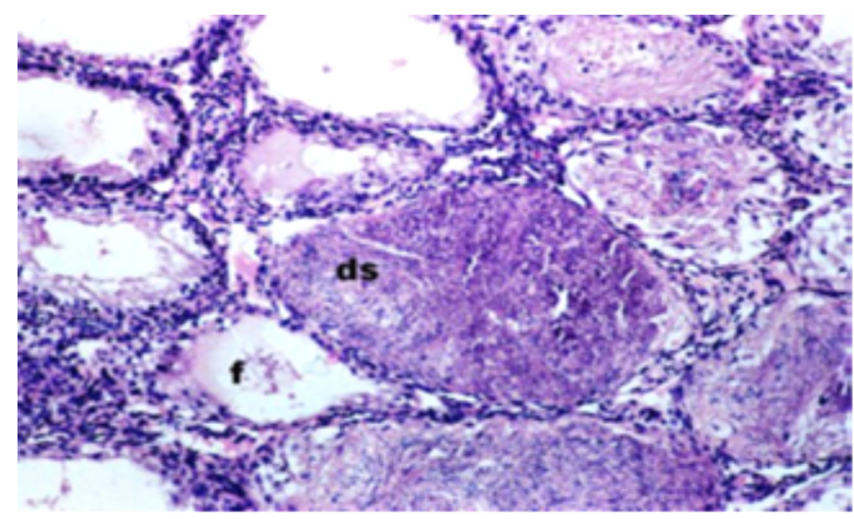

Figure 4: Two weeks of gentamicin injection after 10 week, testis of rat showing coagulative necrosis and degeneration of seminiferous tubules (ds) with fibrosis in between ( $f$ ).

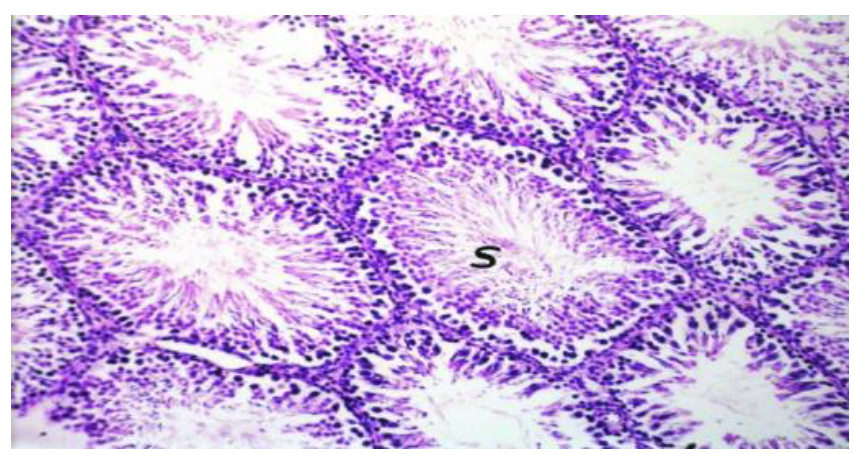

Figure 5: Stem cell therapy, testis showing intact normal histological structure of seminiferous tubules with complete spermatogenic series (s). 
Citation: Mohamed SM, ElHawary NM, Mohamed SF, Hashim NI, Saleh SY, et al. (2017) Effect of Stem Cell Therapy on Gentamicin Induced Testicular Dysfunction in Rats. J Health Med Informat 8: 263. doi: 10.4172/2157-7420.1000263

spermatogenic series with the interstitial tissue stromal cells were localized in between the seminiferous tubules with the blood vessels (Figure 7).

\section{Discussion}

Male infertility is a global population health concern, where there are an estimated 48.5 million couples with infertility worldwide [31], thus the current study focused on gentamicin induced testicular dysfunction and the potential of mesenchymal stem cells to improve this dysfunction. Gentamicin is commonly prescribed for gram negative infections, however, studies have demonstrated that they impair significantly both testicular function and structure [6]. The present study showed that gentamicin injection for 2 weeks resulted in a significant decrease in serum testosterone and Intratesticular testosterone and estradiol at the end of $2^{\text {nd }}, 6^{\text {th }}$ and $10^{\text {th }}$ weeks versus controls rats. The results of the current work are in accordance with Zahedi et al. [32] who found that the levels of testosterone were reduced significantly following exposure to gentamicin. Several studies Yaman \&Balikci [33] demonstrated the ability Yaman \&Balikci [33] of gentamicin to induce oxidative stress by the significant rise in MDA (lipid peroxidation product) coupled with significant decline in the endogenous antioxidants GST, SOD

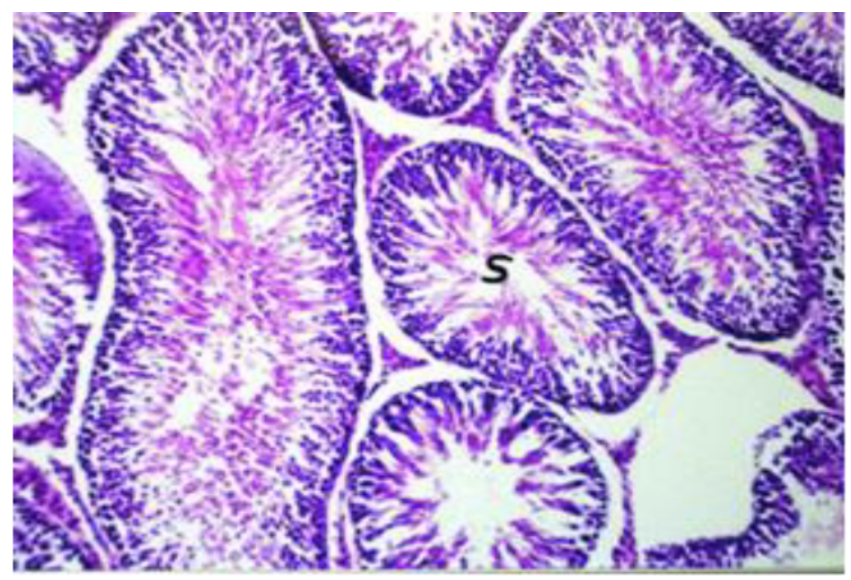

Figure 6: Stem cell therapy and 2 weeks of gentamicin injection at $6^{\text {th }}$ weeks testis showing normal histological structure with interstitial stromal triangular area between the seminiferous tubule (s).

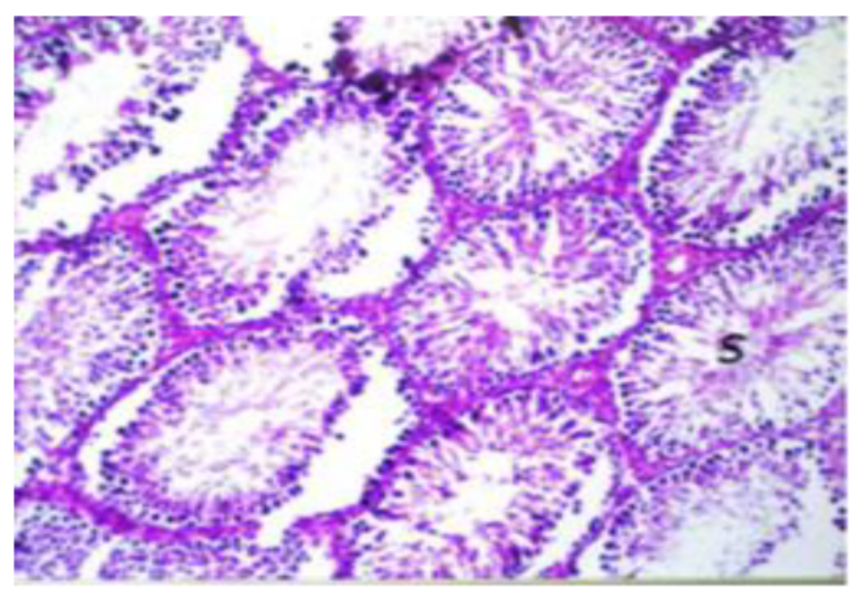

Figure 7: Stem cell therapy and 2 weeks of gentamicin injection at $10^{\text {th }}$ week testis showing normal histological structure with interstitial stromal triangular area between the seminiferous tubule (s) (H\&E X400). and CAT. The increased lipid peroxidation lead to inactivation of the enzymes by crosses linking with MDA; this will cause an increased accumulation of superoxide, $\mathrm{H} 2 \mathrm{O} 2$ and hydroxyl radicals which could further stimulate lipid peroxidation [34]. The reduced testosterone and estradiol levels (in serum and/or tissue) in the present study can be also attributed to the direct damaging effect of gentamicin on Leydig cells. This is supported by the histopathological changes in the present study in the form of interstitial edema and degenerated Leydig cells which appeared dark and edematous after gentamicin injection. This is in line with Khaki et al. [41] who revealed that necrosis of the interstitial cells by gentamicin resulted in decreased synthesis of this hormone. Also, inhibition of steroidogenesis by gentamicin might be due to increasing tumor necrosis factor alpha (TNF- $\alpha$ ) gene expression as agreed by Zager et al. [35] who demonstrated that TNF- $\alpha$ gene expression was doubled after gentamicin administration. The increased (TNF- $\alpha$ ) gene inhibits steroidogenesis in Leydig cells at the transcriptional level of steroidogenic enzymes [36,37]. In rodents, Leydig cells synthesize oestrogen in adults; moreover, it has been shown that germ cells (especially spermatid) from adult male rat account for half of the testicular source of oestrogens through aromatization [38].

\section{Effect of gentamicin on \% of fragmented DNA in testicular tissue}

The present study showed that gentamicin injection for 2 weeks resulted in a significant increase in \% of fragmented DNA in testicular tissue at the end of $2^{\text {nd }}, 6^{\text {th }}$ and $10^{\text {th }}$ weeks versus control rats. This result may be attributed to gentamicin induced testicular oxidative damage. This seems to be true as Akondi et al. [29] found that oxidative damage can cause base degradation, DNA fragmentation and cross-linking of proteins, moreover, the reduced activity of antioxidants increases DNA damage $[39,40]$.

\section{Effect of gentamicin on sperm count and viability}

The present study showed that gentamicin injection for 2 weeks resulted in a significant decrease in sperm count and viability at the end of $2^{\text {nd }}, 6^{\text {th }}$ and $10^{\text {th }}$ weeks versus control rats. The present results are in consistence with Khaki et al. [41] who claimed that gentamicin reduced sperm count, sperm motility, and sperm viability. Gentamicin induction of oxidative stress-status in the testis by increasing free radical formation and lipid peroxidation resulted in germ cell apoptosis and subsequent hypo spermatogenesis [42]. Another mechanism by which gentamicin can decrease the sperm count is by diminution of testicular ascorbic acid. This is in agreement with Adewoyin et al.[43] who stated that gentamicin causes mobilization of ascorbic acid from the testis that maintains antioxidant activity. The decrease in sperm count by gentamicin is supported by the reduction in serum and intra testicular testosterone levels induced by gentamicin in the present work as testosterone is essential for the initiation and progression of normal spermatogenesis. Both testosterone and FSH bind to target receptors on the Sertoli cells and inhibit death signals sent to germ cells [44].

\section{Effect of gentamicin on histopathology of the testis}

The histopathological examination of testicular tissue in the present work showed degenerative changes in the seminiferous tubules and epididymis that persisted after $2^{\text {nd }}, 6^{\text {th }}$ and $10^{\text {th }}$ weeks of gentamicin injection. This finding has been strongly supported by Demir et al. [6] who observed that gentamicin has negative effect on testis architecture in rats that included epithelial cell sloughing, atrophic changes and decrease in germ cell numbers due to cytotoxicity of gentamicin. They added that degenerative changes in the seminiferous tubules and decrease of spermatozoa in the testis, epididymis are the evidence for 
genotoxicity.

Furthermore In experimental circumstances in which the intra testicular testosterone concentration is reduced a significant germ cell death is seen thus degenerative changes observed in the seminiferous tubules by gentamicin may be correlated to the decreased intra testicular testosterone in the present study. Another explanation for gentamicin induced testicular degeneration may be through the generation of reactive oxygen species, as superoxide, hydrogen peroxide and hydroxyl radical which frequently used to produce oxidative and necrotic damages [45]. This is supported by the appearance of giant cells in seminiferous tubules in gentamicin injected group III in the current work these giant cells are actively engaged in free radical production [46].

\section{Effect of stem cell therapy on serum testosterone and testicular testosterone and estradiol}

In the current study, stem cell therapy protected the testis against gentamicin toxicity by significant increase in serum testosterone and testicular testosterone and estradiol levels in testicular tissue at the end of $6^{\text {th }}$ and $10^{\text {th }}$ weeks after 2 weeks of gentamicin injection. Serum testosterone levels returned nearly to control values with stem cell therapy in gentamicin injected group. As regard to the testicular tissue testosterone, the levels returned to control values with stem cell therapy in gentamicin injected group while estradiol levels returned nearly to control values with stem cell therapy only at the $10^{\text {th }}$ week of gentamicin injection. These results are in agreement with Cakici et al. [47] who reported that treatment of male infertility and testosterone deficiency was possible by adult stem cells. In accordance with our results also, Wu et al. [48] reported that MSCs from human bone marrow are able to differentiate into steroidogenic or testicular Leydig cells in vitro. Also the differentiation of BM-MSCs into germ cells, and Sertoli cells was demonstrated in busulfan-treated infertile mice [49].

\section{Effect of stem cell therapy on \% of fragmented DNA in testicular tissue after gentamicin injection}

In the present work, stem cell therapy produced a significant decrease in \% of fragmented DNA in testicular tissue at the end of $6^{\text {th }}$ and $10^{\text {th }}$ weeks after gentamicin injection for 2 weeks. Percentage of fragmented DNA returned nearly to control values with stem cell therapy in gentamicin injected group.

The decrease in \% of fragmented DNA in gentamicin injected rats after stem cell therapy may be correlated to the direct role for stem cells in protection against oxidative damage by their antioxidant properties. This seems to be true since Ping et al.[50] reported that mesenchymal stem cells possess antioxidant ROS-scavenging capacity and are resistant to hydrogen peroxide-induced apoptosis or ionizing radiation. This resistance to ROS were attributed to factors secreted by the mesenchymal stem cells as IGF, PDGF, SOD, IL-6, G-CSF, GMCSF, IL-12 cytosolic superoxide dismutase, mitochondrial superoxide dismutase, catalase and glutathione peroxidasel enzymes and also depends on the high level of intracellular total glutathione [51,52]. Moreover stem cells have high antiapoptotic activity due to over express Bcl-2, the key antiapoptotic protein [53].

\section{Effect of stem cell therapy on sperm count and viability}

There are some reports to show that, injecting of MSCs into the atrophic seminiferous tubules could improve infertility and provided functional data in support of stem cell self-renewal, and increase in the number of stem cell. In the present work, stem cell therapy produced a significant increase in sperm count and viability at the end of $6^{\text {th }}$ and $10^{\text {th }}$ weeks after gentamicin injection for 2 weeks. Sperm count and viability returned nearly to control values with stem cell therapy in gentamicin injected group. The present results are in consistence with Hua et al [54]. who reported that stem cells experimentally derived from bone marrow have been recently used in experimental busulfan-treated infertility rodent models. The function of BM-MSCs in spermatogenesis might be direct (trans-differentiation), or they interact with the cellular microenvironment (niche) of testis tissue. Moreover, Easley et al. [55] reported that Induced Pluripotent Stem Cells (iPSCs) have the ability to differentiate directly into advanced germ cell lineages in vitro such as postmeiotic, spermatid-like cells without genetic manipulation but not into spermatogonia, haploid spermatocytes, or spermatids. In contrast to the results of the present work, Lassalle et al. [56] demonstrated that male bone marrowderived stem cells did not undergo spermatogenesis when transplanted into the testis of adult mice. In contradiction with the results of the current work Nayemia et.al [57] demonstrated that concerning male germinal lineage, mouse adult bone marrow mesenchymal stem cells, grown in vitro in the presence of retinoic acid, were found to express germ cell markers, but they failed to undergo spermatogenesis after transplantation into testes. A similar Trans differentiation process was described for adult human bone marrow cells.

\section{Histopathological findings in the testis after stem cell therapy}

Histopathological examination of the testis in the present study revealed reduction in testicular damage after stem cell therapy after injection of gentamicin for 2 weeks. Structure of seminiferous tubules nearly returned to normal after gentamicin injection so, it is not surprising that this improvement in testicular structure led to improvement in all tested parameters in the present study. Therefore, testicular hormones (testosterone and in estradiol) and the fragmented DNA returned to normal value There were improvement also in semen quality as sperm count and viability increased.

\section{Conclusion}

In conclusion, the present study is a recent proof of the potential therapeutic effect of bone marrow derived mesenchymal stem cells in male infertility, with explanation of possible mechanisms of action of these cells.

\section{References}

1. Shefi S, Paul J, Turek PJ (2006) Definition and current evaluation of subfertile men. Int Braz J Urol 32: 385-397.

2. Agarwal A, Mulgund A, Hamada A, Chyatte MRA (2015) Unique view on male infertility around the globe. Reprod Biol Endocrinol 26: 37.

3. Sigman M (2011) Male infertility. In: Wein AJ et al. (eds.) Campbell-Walsh Urology ( $9^{\text {th }}$ edn.). Philadelphia, PA: Saunders Elsevier.

4. Jungwirth A, Giwercman A, Tournaye HC, Diemer T, Kopa Z, et al. (2012) European Association of Urology Guidelines on Male Infertility: The 2012 Update. Europ Urol 62: 324-332.

5. Oliva A, Giami A, Multigner L (2002) Environmental agents and erectile dysfunction: a study in a consulting population. J Androl 23: 546-550.

6. Demir A, Turker P, Onol FF, Sirvanci S, Findik A (2007) Effect of experimentally induced Escherichia coli epididymo-orchitis and Ciprofloxacin treatment on rat spermatogenesis. Int J Urol 14: 268-272.

7. Herbold BA, Brendler SY, Ahr HJ (2001) Ciprofloxacin: in vivo genotoxicity studies. Mutat Res 498: 193-205.

8. Soliman KM, Abdul-Hamid M, Othman AO (2007) Effect of carnosine on gentamicin-induced nephrotoxicity. Med Sci Monit 13: 73-83. 
Citation: Mohamed SM, ElHawary NM, Mohamed SF, Hashim NI, Saleh SY, et al. (2017) Effect of Stem Cell Therapy on Gentamicin Induced Testicular Dysfunction in Rats. J Health Med Informat 8: 263. doi: 10.4172/2157-7420.1000263

9. Sundin DP, Sandoval R, Molitoris BA (2001) Gentamicin inhibits renal protein and phospholipid metabolism in rats: implications involving intracellular trafficking. J Am Soc Nephrol 12: 114-123.

10. Li H, Kachelmeier A, Furness DN, Steyge PS (2015) Local mechanisms fo loud sound-enhanced aminoglycoside entry into outer hair cells. Front Cell Neurosci 9: 1-10

11. Watt FM, Driskell R (2010) The therapeutic potential of stem cells. Philos Trans R Soc Lond B Biol Sci 365: 155-163.

12. Ehninger A, Trumpp A (2011) The bone marrow stem cell niche grows up: mesenchymal stem cells and macrophages move in. JEM 208: 421-428.

13. Lee HJ, Kang KS, Kang SY, Kim HS, Park SJ, et al. (2016) Immunologic properties of differentiated and undifferentiated mesenchymal stem cells derived from umbilical cord blood. J Vet Sci 17: 289-297.

14. Tse WT, Pendleton JD, Beyer WM, Egalka MC, Guinani EC (2003) Suppression of allogeneic $T$ cell proliferation by human marrow stromal cells: implications. Transplantation 75: 389-397.

15. Liu P, Lin J, Zhang B (2005) Differential regulation of cadherin expression by osteotropic hormones and growth factors in vitro in human osteoprogenitor cells. Acta Pharmacologica Sinica 26: 705-713.

16. Singec I, Jandial R, Crain A, Nikkhah G, Snyder EY (2007) The leading edge of stem cell therapeutics. Annu Rev Med 58: 313-328.

17. Strauer B, Steinhoff G (2011) 10 years of intracoronary and intramyocardial bone marrow stem cell therapy of the heart: from the methodological origin to clinical practice. J Am Coll Cardiol 58: 1095-1104.

18. Yan L, Han Y, He Y, Xie H, Liu J, et al. (2007) Cell tracing techniques in stem cell transplantation. Stem Cell Rev 3: 265-269.

19. Bancroft JD, Gamble M (2002) Theory and practice of histological techniques ( $5^{\text {th }}$ edn.). NY, USA: Churchill Livingstone.

20. Adamkovicova M, Toman R, Martiniakova M, Omelka R, Babosova R, et al (2016) Sperm motility and morphology changes in rats exposed to cadmium and diazinon. Reprod Biol Endocrinol 14: 1-10.

21. Alhadlaq A, Mao JJ (2004) Mesenchymal stem cell: isolation and therapeutics. Stem cells Dev 13: 436-448.

22. Patel DM, Shah J, Srivastava AS (2013) Therapeutic potential of mesenchyma stem cells in regenerative medicine. St Cel Int 2013: 1-15.

23. Ghoraishizadeh P, Raikarv S, Ghorishizadeh A, Boroojerdi MH, Daneshvar N (2014) Biology, properties and clinical application of mesenchymal stem cells, macro- and micromorphology. ROMJ 3: 1-7.

24. Rochefort GY, Vaudin P, Bonnet N, Pages JC, Domenech J, et al. (2005) Influence of hypoxia on the domiciliation of mesenchymal stem cell after infusion into rats: possibilities of targeting pulmonary artery remodeling via cells therapies. Respir Res 6: 125.

25. Williams JF (1989) Optimization strategies for the polymerase chain reaction. Biotechniques 7: 762-769

26. Wayne PA (1998) National committee for clinical laboratory standers. NCCLS.

27. Gore RE (1988) Follicular steroidogenesis and its control. In: The physiology of Reproduction 1: 331-385.

28. Boraschi D, Maurizi G (1996) Quantitation of DNA fragmentation with diphenylamine. Lab Man Exper Method 24: 992-993.

29. Drury R, Wallington E (1980) Electron microscopic techniques. In: Carlton's Histological Techniques ( $5^{\text {th }}$ edn.) Drury and Wallington edition. Oxf Univ Press 1: 93-99.

30. Snedecor GM, Cochran WG (1980) Statistical analysis.

31. Mascarenhas MN, Flaxman SR, Boerma T, Vanderpoel S, Stevens GA (2012) National, regional, and global trends in infertility prevalence since 1990: a systematic analysis of 277 health surveys. PLoS Med 9: e1001356.

32. Zahedi A, Khaki A, Ahmadi-Ashtiani HR, Rastegar H, Rezazadeh SH (2010) Zingiber officinale Protective Effects on Gentamicin's Toxicity on Sperm in Rats. J Med Plan 35: 93-98.

33. Yaman I, Balikci (2010) Protective effects of Nigella sativa against gentamicininduced nephrotoxicity in rats. Exp Toxicol Pathol 62: 183-190.
34. Heeba GH (2011) Angiotensin 2 receptor blocker, losartan, ameliorates gentamicin-induced oxidative stress and nephrotoxicity in rats. Pharmacol 87 232-240.

35. Zager RA, Johnson AC, Geballe A (2007) Gentamicin suppresses endotoxindriven TNF-alpha production in human and mouse proximal tubule cells. Am J Physiol Renal Physiol 293: 1373-1380.

36. Hong SH, Park SK, Cho YS, Lee HS, Kim KR (2006) Gentamicin induced nitric oxide-related oxidative damages on vestibular afferents in the guinea pig. Hear Res 211: 46-53.

37. King EB, Salt AN, Kel GE, Eastwood HT, O'Leary SJ (2013) Gentamicin administration on the stapes footplate causes greater hearing loss and vestibulotoxicity than round window administration in guinea pigs. Hear Res 304: 159-166.

38. Carreau S, Bourguiba S, Marie E (2004) Testicular and blood steroid levels in aged men. Bio Reprod 4: 299-304.

39. Akondi B, Akula A, Challa SR (2011) Protective Effects of Rutin and Naringin on Gentamycin Induced Testicular Oxidative Stress. Eur J Gen Med 8: 57-64.

40. Murawska E, Wojciech BL, Zawadzki M, Rychel J, Zuwała-Jagieło J (2012) Oxidative stress level in the testes of mice and rats during nickel intoxication.

41. Khaki A, Novin MG, Khaki AA, Fathiazad F, Morteza Khaberi M, et al. (2009) Ultrastructural study of gentamicin and ofloxacin effect on testis tissue in rats: Light and transmission electron microscopy. Afric J Pharm Pharmacol 3: 105-109.

42. Turner T, Lysiak J (2008) Oxidative stress: a common factor in testicular dysfunction. J Androl 29: 488-498.

43. Adewoyin M, Ibrahim M, Roszaman R, Isa M, Alewi N, et al. (2017) Male infertility: the effect of natural antioxidants and phytocompounds on seminal oxidative stress. Diseases 5: 1-26.

44. Shaha C, Tripathi R, Mishra DP (2010) Male germ cell apoptosis: regulation and biology. Philos Trans R Soc Lond B Biol Sci 365: 1501-1515.

45. Khaki A (2015) Assessment on the adverse effects of Aminoglycosides and Flouroquinolone on sperm parameters and male reproductive tissue: $A$ systematic review. Iran J Reprod Med 13: 125-134.

46. Parlaktas BS, Atilgan D, Ozyurt H, Gencten Y, Akbas A, et al. (2014) The biochemical effects of ischemia-reperfusion injury in the ipsilateral and contralateral testes of rats and the protective role of melatonin. Asian $\mathrm{J}$ Androl 16: $314-318$

47. Cakici C, Buyrukcu B, Duruksu G, Haliloglu, AH, Akosy A, et al. (2013) Recovery of fertility in azoospermia rats after injection of adipose-tissue-derived mesenchymal stem cells: the sperm generation. BioMed Rese Int 2013: 1-18.

48. Wu YJ, Dong Q, Li SF, Wei X, Long D, et al. (2012) Differentiation of human bone marrow mesenchymal stem cells into Leydig or steroidogenic cells in vitro. Sichuan Da Xue Xue Bao Yi Xue Ban 43: 493-506.

49. Lue Y, Erkkila K, Liu PY, Ma K, Wang C, et al. (2007) Fate of bone marrow stem cells transplanted into the testis: potential implication for men with testicular failure. Am J Pathol 170: 899-908

50. Peng L, Jia Z, Yin X, Zhang X, Liu Y, et al. (2008). Comparative analysis of mesenchymal stem cells from bone marrow, cartilage, and adipose tissue. Stem Cells Dev 17: 761-773.

51. Kato Y, Iwata T, Morikawa S, Yamato M, Okano T, Uchigata Y (2015) Allogeneic transplantation of an adipose-derived stem cell sheet combined with artificia skin accelerates wound healing in a rat wound model of type 2 diabetes and obesity. Diabetes 64: 2723-2734.

52. Liu Q, Guan J, Sun Y, Le Z, Zhang P, et al. (2017) Insulin-like growth factor 1 receptor-mediated cell survival in hypoxia depends on the promotion of autophagy via suppression of the $\mathrm{PI} 3 \mathrm{~K} / \mathrm{Akt} / \mathrm{mTOR}$ signaling pathway. Mol Med Rep 15: 2136-2142.

53. Sekhon BS (2010) Metalloantibiotics and antibiotic mimics-an overview. Pharm Educ Res I: 1-10.

54. Hua J, Qiu P, Zhu H, Cao H, Wang F, et al. (2011). Multipotent mesenchymal stem cells (MSCs) from human umbilical cord: potential differentiation of germ cells. Afr J Biochem Res 5: 113-123. 
Citation: Mohamed SM, ElHawary NM, Mohamed SF, Hashim NI, Saleh SY, et al. (2017) Effect of Stem Cell Therapy on Gentamicin Induced Testicular Dysfunction in Rats. J Health Med Informat 8: 263. doi: 10.4172/2157-7420.1000263

Page 8 of 8

55. Easley CA, Phillips BT, Guire MM, Barringer JM, Valli H, et al. (2012) Direct differentiation of human pluripotent stem cells into haploid spermatogenic cells. Cell Rep 2: 440-446.

56. Lassalle B, Mouthon MA, Riou L, Barroca V, Coureuil M, et al. (2008). Bone marrow-derived stem cells do not reconstitute spermatogenesis in vivo. Stem Cells 26: $1385-1386$.

57. Nayernia K, Lee JH, Drusenheimer N, Nolte J, Wulf G, et al. (2006) Derivation of male germ cells from bone marrow stem cells. Lab Invest 86: 654-663. 